\title{
Financial Development and Monetary Transmission Mechanism in Nigeria (1986- 2017)
}

\section{Olajide Oyadeyi ${ }^{1}$ Temidayo Akinbobola ${ }^{2}$}

'Student, Obafemi Awolowo University, Nigeria.

Email:jide.oyadeyi@gmail.com Tel: +2948020909614

${ }^{2}$ Head and Professor of International Economics, Obafemi Awolowo University, Nigeria.

Email:tbobola@yahoo.co.uk Tel: +2348037172271

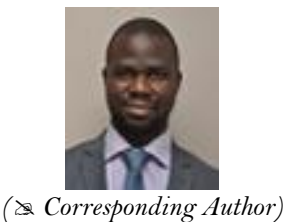

\begin{abstract}
This study explored the impacts of the different aspects of financial development on monetary transmission mechanism in Nigeria from the period of 1986-2017 using quarterly data. Variables such as broad money supply, debt stock, stock market capitalization, stock market value traded, total deposit money bank's asset, total financial assets, private sector credit, inflation rate, monetary policy rate, exchange rate, all share index and output, were used to carry out this investigation. The study adopted Pesaran, Shin, and Smith (2001) ARDL framework to check the impacts of these individual financial development indicators and how they affect monetary transmission mechanism. The findings suggested that financial development indicators and their interactions with the policy rate influenced each channel of monetary policy with different degrees. Banking sector indicators (size and activity measures) had more influence on the channels of monetary policy transmission compared to capital market indicators, while financial market liberalization had the least influence on the channels of monetary policy transmission. However, the significance of the individual financial development indicators was found to be very weak on exchange rate channel, while the influence of the financial market indicators was strongest on the interest rate channel, thereby supporting previous studies that interest rate channel is the most dominant channel of monetary policy for Nigeria. Finally, the paper recommended that financial reforms must be geared towards strengthening the implementation of monetary policy and the channels through which monetary policies impact real economic activity.
\end{abstract}

Keywords: Financial development, Monetary policy, Monetary transmission mechanism, Banking sector development, Stock market development, Bond market development, Financial liberalization.

JEL Classification: E44, E50, E52.

Citation | Olajide Oyadeyi; Temidayo Akinbobola (2020). Financial Development and Monetary Transmission Mechanism in Nigeria (1986-2017). Asian Journal of Economics and Empirical Research, 7(1): 74-90.

History:

Received: 8 January 2020

Revised: 19 February 2020

Accepted. 23 March 2020

Accepted: 23 March 2020

Published. 16 April 2020 licensed under a Creative Commons

Attribution 3.0 License (cc)

Publisher: Asian Online Journal Publishing Group
Acknowledgement: Both authors contributed to the conception and design of the study.

Funding: This study received no specific financial support

Competing Interests: The authors declare that they have no conflict of interests.

Transparency: The authors confirm that the manuscript is an honest, accurate, and transparent account of the study was reported; that no vital features of the study have been omitted; and that any discrepancies from the study as planned have been explained.

Ethical: This study follows all ethical practices during writing.

\section{Contents}

1. Introduction ...

2. Review of Empirical Literature.

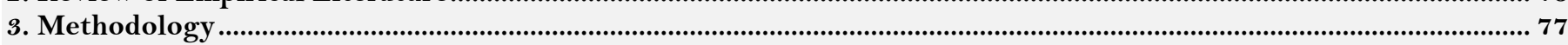

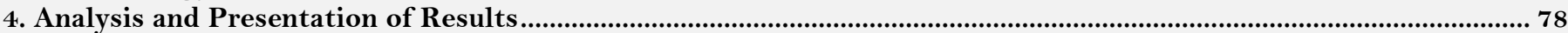

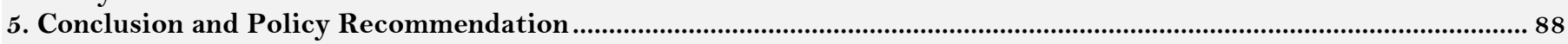

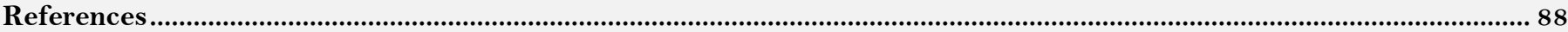

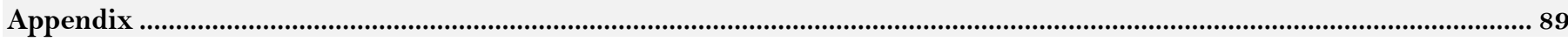




\section{Contribution of this paper to the literature}

This study explored the impacts of the different aspects of financial development on monetary transmission mechanism in Nigeria from the period of 1986-2017 using quarterly data.

\section{Introduction}

Financial sector development potentially plays an important and fundamental role with the general growth or development in any economy. Central to the financial sector are banks. They are the conduit through which funds flow within an economy. Their major role involves intermediation, that is, moving funds from the surplus agents to deficit units. These banks are divided into banking and non-banking financial institutions. The banking financial institutions are also known as deposit taking institutions. They move funds from surplus agents to the deficit units. Typical examples of these deposit taking institutions include the Central Bank, commercial banks and the development banks. The non-banking institutions are not depository institutions, but they also play the role of channeling funds from surplus to deficit units. Examples of non-banking institutions are investment banks, contractual savings institutions ${ }^{1}$, insurance companies, payday lenders, cooperative societies, institutional investors, finance companies ${ }^{2}$ and so on. By implication, how an economy manages these institutions largely depend on the extent of development within the financial system and the monetary transmission framework available in any economy (Visco, 2007).

On the global scene, financial sector reforms have improved the competitive and profitability levels globally vis-a-vis the introduction of market-based instruments, the removal of financial market and capital account restrictions and the liberalization of these markets to promote innovation and competition (Goldberg, 2013; Spiegel, 2008). Consequently, financial sector developments have provided the guidance and foundations for globally competitive economies and improving the growth conditions in many economies, since these economies not only produce their goods and services for domestic consumption, but also export these goods and services internationally (Johnston \& Sundararajan, 1999). In Nigeria, financial sector reforms have taken the form of financial market liberalization and deregulation. These liberalization policies took effect in the 80 s, with the introduction of Structural Adjustment Program (SAP) instituted by International Monetary Fund (Adesoye, 2014). Here, indirect or market-based instruments were adopted to achieve the ultimate objectives of price stability and sustainable growth (Akpan, 2011). The policy also ensured private sector restrictions were removed to encourage more private sector participation in improving the economy (Akpan, 2011). However, policy inconsistency and implementation problems have affected the extent through which these reforms affected monetary policy transmission and consequently, macroeconomic performance.

Monetary transmission mechanism is a description of how monetary policy is being transmitted into an economy via several channels. Its effectiveness hinges greatly on the extent of development within the financial system. However, it is a known fact that the Nigerian financial system is one of the most underdeveloped financial institutions in the world today and there are worrying features of the system. First of all, Nigeria still has an undiversified and unspecialized banking system (Babajide, 2011). This means that several institutions overlap in performing other sector functions. Take for instance, commercial banks are expected to provide retail banking services to customers but they also engage in providing wholesale transactions. Same as the merchant banks as well as other banks. The difference in their performance lies in the quality of service and value added. Furthermore, these institutions both lend to corporate bodies, governments and individuals and are mostly structured in urban areas (Babajide, 2011). The only exceptions to this case in terms of functions are the insurance companies and development banks who perform their main obligations.

As earlier stated, financial sector development is very important in the conduct and performance of any economy (Claus \& Grimes, 2003; Visco, 2007). This is because the effectiveness of transmitting monetary policy into an economy depends on the structure and functioning of the financial system. This role has been solely given to the central banks because a stable and sound financial system is arguably a pre-condition for the effective adoption of monetary policy operations within an economy (Claus \& Grimes, 2003). Even though there has been some evidence in the literature ${ }^{3}$ about past researches on financial development and monetary policy in Nigeria, the effects of financial development on monetary transmission mechanism are yet to be ascertained for Nigeria. Furthermore, and as a deviation from other studies", this study intends to measure how the different aspects of the financial sector has been able to affect the different transmission channels through which monetary policy may influence an economy. Thus, banking sector development, capital market development, bond market development as well as financial liberalization were used to model financial sector developments in Nigeria, while the different channels of monetary policy that were examined include interest rate channel, exchange rate channel, credit channel, asset price channel as well as expectations channel.

In addition, this paper also explored the joint interaction between financial development and monetary policy on each channel of monetary policy. The essence of this is to be able to determine if financial development and its interaction with the policy rate can be used as policy tools to strengthen monetary transmission mechanism in Nigeria. Finally, this study examines the role of structural breaks in modelling this relationship in Nigeria. The consensus in the literature is that the incorporation of structural break or reform issues in the modeling of monetary policy and its transmission is methodologically imperative (Doguwa, Olowofeso, Uyaebo, Adamu, \& Bada, 2014). Therefore, this study will examine the impact of financial development on each monetary policy channel in Nigeria and it is therefore expected that the findings of this study would provide more understanding on the linkages between financial development and monetary transmission mechanism in Nigeria. The rest of the paper is organized as follows: section two reviews the empirical literature, while section three focuses on the methodology. Section four presents the results, while the final section concludes the paper with some policy recommendations. 


\section{Review of Empirical Literature}

\subsection{Developed Country Review on Financial Development and Monetary Policy Transmission}

There are quite a number of studies on the relationship between financial development and monetary policy transmission in developed and developing countries. Earliest among them are the works of Brunner and Meltzer (1963). Their paper examined the effect of financial intermediaries on the transmission channels of monetary policy in the US. The study showed that a pure flow analysis misreads the significance of many flow magnitudes. That is, they are more appropriately interpreted as adjustment flows in a wealth allocation process. These remarks, most unfortunately, cannot justify in any sense the wealth adjustment hypothesis of money, interest, and income that was specified. The study however suggested that these remarks point to directions of research permitting an appraisal relative to standard-flow conceptions. In 2002, Bean, Larsen, and Nikolov (2002) using cross correlation and VAR analysis evaluated the role of financial frictions in the monetary transmission mechanism on the Euro area from 1970 to 2000 . The study found out that financial frictions and their asymmetric nature may lead to uncertainties in determining the period the economy will adjust to monetary policy changes.

Christensen et al. (2006) modelled financial channels for monetary policy analysis in Canada using financialaccelerator mechanism, ToTEM models and DSGE models. The study indicated that adopting these methodologies are crucial and are capable of addressing policy issues within an economy. Similarly, Devereux and Sutherland (2007) examined the relationship between financial globalization and monetary policy in Canada using the DSGE framework. The results generally suggested that while an improvement in financial globalization affects the framework in the operation of monetary policy, it may not affect the core objectives of optimal monetary policy. However, Singh, Razi, Endut, and Ramlee (2007) examined how the monetary transmission mechanism is affected by financial market developments in Asian countries in relation to developed countries of the world from the period of 1980 to 2006. The study suggested that financial development led to a strengthened interest rate pass-through in Asian financial markets, both in the short and long run with faster adjustment speed. Furthermore, the study revealed that developed countries are characterized by a lower degree of interest rate pass-through.

In the same way as Bean et al. (2002); Visco (2007) investigated the connection between financial deepening and the monetary transmission mechanism in the European area. The study suggested that financial liberalization may now make it more difficult to pursue dual objectives in terms of inflation and exchange rates. Spiegel (2008) reexamined the impact of financial globalization on monetary policy in 127 countries (OECD countries and other developed countries) from the period of 1980 to 2004 . The study also suggested that it would prove a challenging task to establish a sound relationship between financial openness and monetary policy. However, Alpanda and Aysun (2012) studied the relationship between global banking and the balance sheet channel of monetary transmission mechanism in the US. The results revealed that improved banking operations may have led to the improved effectiveness in the conduct and performance of the Federal Reserve, thus strengthening the balance sheet channel. Finally, the result affirmed the theoretically positive relationship between bank globalization and the balance sheet channel of monetary policy.

Correspondingly, Aysun, Brady, and Honig (2012) also examined the effect of financial frictions on the strength of the credit channel of monetary transmission of 61 developed countries, using monthly data and spanning the period 1984 M1 to 2008 M5. The study revealed the dominance of the credit channel with countries that possess a high financial friction level. Furthermore, the study revealed that monetary policy had a greater influence on external finance premiums, by directly influencing asset prices, as well as borrower's leverage. Using Structural VAR (SVAR) models on cross-country data, the study revealed the theoretically positive relationship between financial frictions and the strength of the credit channel.

Similarly, Goldberg (2013) empirically investigated the relationship among banking globalization, transmission and monetary policy autonomy for 113 countries from the period of 1995 to 2009. The study revealed that expansion of global banks as they enter other countries tend to reduce their frictions in international capital flows. In Europe, Billi and Vredin (2014) examined the nexus between monetary policy and financial stability in Sweden. The study was of the view that since the macro-prudential models that were adopted prior to the financial crises could not predict the crises, then these macro-prudential policies were insignificant, but they provided useful guidance on the relationship between financial stability and monetary policy. In contrast, Kryvtsov, Molico, and Tomlin (2015) carried out an empirical investigation on the relationship between monetary policy and financial stability since financial system stability should influence monetary transmission mechanism in Canada. The study showed that monetary policy cannot be devoid of financial stability problems and that monetary policy conduct can also be influenced by strong macroprudential policies.

Tayssir and Feryel (2017) reviewed the question whether central banks and their monetary policies promote financial development. The paper employed methods of linking financial development and measures of central bank variables using a panel framework. The sample period was made up of a panel of 22 countries over the period 1980 to 2010 , using the VAR methodology. The study used several macroeconomic variables, institutional quality variables and several measures of financial development. The results revealed that monetary policy and other central bank characteristics significantly influenced financial development for all the observed countries.

\subsection{Developing Country Review on Financial Development and Monetary Policy Transmission}

Ikhide (1996) reviewed the impact of financial liberalization on monetary policy in Nigeria, with a focus on the transition from the direct monetary policy regime to the indirect monetary policy regime. The study through the use of OLS technique concluded that a range of measures were needed in restructuring insolvent banks, and a new policy should be introduced to deal with offending market participants. Furthermore, the study revealed that the secondary market needs to be further developed. The study also noted that even if all these were achieved, there was still a need for the government to improve the fiscal deficit conditions and remove interest rate ceilings for the money market to function efficiently. In Thailand, Sirivedhin (1998) examined the relationship that exist between reforms in the financial system and monetary transmission mechanism in Thailand from the period of 1989 to 1995. Using a VAR model, the study revealed that interest rate channel has become more effective over the years due to the influence from foreign interest rates. The study further confirmed that the liberalization of financial 
markets improved the process of financial deepening, thereby increasing access to investments in a range of financial assets.

In New Zealand however, Claus. and Smith (1999) examined the role of financial intermediaries and the credit channel of monetary transmission mechanism in New Zealand from the year 1982 to 1999. The study was of the view that the financial system as well as the credit markets may have affected the real economy. Furthermore, financial frictions as well as asymmetric information within credit markets may have increased the impact of monetary policy on interest rates, thus affecting inflation and output. In Chile, Alfaro, Franken, García, and Jara (2003) carried out a study on bank lending channel and the monetary transmission mechanism in Chile during the period 1990 to 2002 using data from both the banking sector and the corporate sector. The study concluded that the bank-lending channel was the main channel of monetary policy transmission for Chile.

Claus and Grimes (2003) critically reviewed asymmetric information, financial intermediation and the monetary transmission mechanism in New Zealand. The paper suggested that information and transaction costs were at the heart of the assumptions upon which the Modigliani-Miller theorem was based, therefore, making them important for monetary transmission mechanism. The paper further suggested that the models adopted by macroeconomists were not practicable as these models do not incorporate the significance of financial intermediaries in the credit markets. On the contrary, Mohan (2006) examined the nexus between financial sector reforms and monetary policy in India between 1969 and 2005 using descriptive and econometric techniques. The study revealed that monetary policy was able to maintain price stability and credit availability to support investment and growth for the Indian economy.

Spiegel (2008) reexamined the impact of financial globalization on monetary policy in Sub-Saharan Africa from the period of 1980 to 2004. The results confirmed an inverse relationship between median inflation and financial globalization in the baseline model. In a panel study, Nissanke (2010) carried out a study on the global financial crisis and the developing world by looking in depth at the transmission channels, fall-outs for industrial development and possible implications for industries and welfare of 36 developing countries using dynamic panel methodology. The study revealed that due to the financial crises, foreign investments tend to reduce significantly since these developing countries in most cases do not possess the resources needed to take advantage of foreign investments. However, Montiel, Adam, Mbowe, and O'Connell (2012) carried out a study to determine the relationship between financial architecture and the monetary transmission mechanism in Tanzania from 2001 to 2010. The empirical results suggested that the monetary authorities in Tanzania does not have the impetus for a strong short-term stabilization policy. Furthermore, transmission to the loan rate also appeared to be particularly very weak.

Ozşuca (2012) carried out a study on banks and monetary policy transmission mechanism in Turkey. The results found out that the bank lending channel was efficient for the period of 1988-2001, and its impact became stronger afterwards. The findings also showed that banks' risk-taking behavior responds positively to low interest rate levels for all risk measures. The study concluded that the large and well capitalized banks were less prone to taking risks. Lerskullawat (2014) examined the relationship between financial development and monetary transmission mechanism in Thailand. The study revealed that interest rate affected bank loans negatively in the bank lending channel. In the firms' balance sheet channel however, monetary policy was effective when firms were not faced with financial difficulties and constraints and vice versa when these firms became financially constrained. Lastly, the study found out that measures of financial development had a weaker effect on interest rate vis-à-vis the credit channel, but have a stronger effect on the interest rate vis-a-vis interest rate channel.

On the contrary, Jegede (2014) studied the effects of monetary policy on commercial bank lending in Nigeria between 1988 and 2008. The findings indicated that there exists a long run relationship among the estimated macroeconomic variables. The study's main conclusion was that bank loans and advances were not stirred by monetary policy in the long term; however, their total credit was more receptive to their cash reserves. Similarly, Otalu et al. (2014) in their study examined the relationship between monetary policy and commercial banks performance in Nigeria through the credit creation channel. The study found out that the monetary policy variables affected how commercial banks could create credits. Notwithstanding, the results also confirmed that broad money supply and reserves had a more compelling impact on credit creation compared to any other monetary policy instrument and thus, recommended that effective monetary policy operations is necessary in order to be able to control the available credits that commercial banks make available to the real sector.

On the contrary, Hwa (2015) carried out a study on the transmission of financial stress and its interactions with monetary policy responses in Asian-5 economies (Indonesia, Malaysia, Philippines, Thailand and Singapore) and the US. The study suggested that financial stress negatively influenced the real economy. However, this diminished gradually over the long run. The study also found out that shocks to monetary policy had a significant influence on output gradually and over the long run. Effiong, Esu, and Chuku (2017) carried out an empirical investigation to check whether financial development influenced the effectiveness of monetary policy on output and inflation in Africa from the period of 1990 to 2015, using a panel data set of 39 African countries. The study found a weak influence of financial development on monetary policy effectiveness in Africa. Furthermore, the results showed no relationship between financial development and output growth but a negative relationship between financial development and inflation only at their contemporaneous levels.

\section{Methodology}

In order to examine the impacts of financial development indicators and their interactions with the policy rate on each transmission channel of monetary policy, the ARDL model proposed by Pesaran et al. (2001) was formulated, and this can be expressed as below:

$$
\Delta k_{t}=\alpha+\sum_{j=1}^{p} \theta_{j} \Delta k_{t-j}+\sum_{j=0}^{p} \beta_{j} \Delta f d^{*} m p r_{t-j}+\sum_{j=0}^{p} \gamma_{j} \Delta f d_{t-j}+\sum_{j=0}^{p} v_{j} \Delta d v_{t-j}+\lambda_{1} k_{t-1}+\lambda_{2} f d^{*} m p r_{t-1}+\lambda_{3} f d_{t-1}+\lambda_{4} d v_{t-1}+\varepsilon_{t}
$$


Equation 1 denotes the unrestricted version of ARDL specification which models financial development and its interaction with the policy rate on each transmission channel of monetary policy. Where $\Delta$ is the difference operator; $\alpha$ the drift component, $\mathcal{E}$ is the white noise, $\lambda$ are the long-run multiplier, and $k$ represents interest rate channel, exchange rate channel, credit channel, asset price channel and expectation's channel in each case. Monetary policy rate was used as proxy for the interest rate channel, exchange rate was used as proxy for the exchange rate channel, $\log$ of private sector credit was used as proxy for the credit channel, the log of all share index was used as proxy for the asset price channel, while consumer price index was used as proxy for the expectation channel.

Furthermore, as a deviation from other studies that used money supply or private sector credit to GDP ratio to denote financial sector development, this study develops broader ways of measuring financial sector development. Thus, banking sector development, capital market development, bond market development as well as financial market liberalization was used to represent financial sector development. In addition, $d v$ is used to capture structural breaks in the modelling framework. Also, $f d^{*} m p r$ is meant to capture the interactive effects between financial development and the policy rate. These were with the view of capturing the interactions between financial development and monetary policy as these may have policy implications on the transmission channels of monetary policy.

\section{Analysis and Presentation of Results}

This paper applied quarterly data series from 1986 to 2017 on broad money supply, debt stock, stock market capitalization, stock market value traded, total deposit money bank's asset, total financial assets, private sector credit, inflation rate, monetary policy rate, exchange rate, all share index and real output. These data were sourced from the Central Bank of Nigeria (2017) while data on financial openness was sourced from Chinn and Ito (2017). The descriptive statistic results in Table 1 showed that the mean and median values lie within their maximum and minimum values showing a good level of consistency. Furthermore, financial efficiency displays the least variability with a standard deviation of 0.05 , whereas, the skewness statistics revealed that all the variables were positively skewed except for banking development by size and financial liberalization.

The kurtosis of nine of the variables included in the analysis (BSDA, CMDA, CMDS, FEFF, BMD, INT $\mathrm{LCCH}, \mathrm{EXC}$ and IEC) exceeds three, meaning that the series follows a leptokurtic distribution. This means that the series are greatly peaked relative to the normal distribution (mesokurtic distribution). On the contrary, BSDS, FLO and LASP follows a platykurtic distribution, as their values are less than three, which implies that their distribution is less peaked relative to the normal distribution. Finally, the correlation matrix results in Table 2 showed that each financial development indicator were weakly correlated to each channel of monetary policy, which implies that the evidence of serial correlation was found to be weak among the observed variables.

Since this paper incorporated structural breaks within the framework, then the Zivot and Andrew (1992) and Perron (2006) unit root test were adopted to test the unit root properties of the series. The results in Table 3 indicate that the variables were a mix of being stationary in their level and differenced form.

The bound test result was established in Table 4 in order to investigate if there was a movement from the short to long run. Table 4 showed that at $5 \%$ significance level, there was a movement from the short run to the long run on all financial development indicators on interest rate channel, while the only movements to the long run in the credit channel are from banking sector development by activity measure and bond market innovations. From exchange rate channel, there was no movement from the short to long run, while the asset price result displayed in Table 4 showed that capital market development by size and financial efficiency were the only variables to show a long run movement. Finally, the expectations channel showed that there were long run movements on all financial development indicators except for financial liberalization. The implication of this result is that co-integration exists when there are movements from the short run to the long run.

\subsection{Banking Sector Development and Monetary Transmission Mechanism}

Since the bound test results has been estimated and verified, the next task is to estimate the ARDL model. The analyses of the banking sector results were informed by two separate analysis - banking sector development according to size and banking sector development according to activity. The paper first discusses the results of banking sector development according to size. From Table 5, the previous lags of the dependent variable influenced interest rates in the current period. Furthermore, the interest rate channel result proved that the banking development by size in the current period does not significantly affect interest rate channel. Furthermore, the current and third quarter policy rate significantly affect interest rate channel. Also, when the policy rate interacts with bank development by size, it significantly influenced interest rate channel. Finally, the result of the interaction between bank size and monetary policy displays an overshooting interest rate pass-through. The interpretation of this outcome is that bank assets are highly generated compared to other institutions within the financial system. The implication of this result is that a bigger bank size leads to a higher level of financial intermediation; however, banks would have less influence on their deposits and lending. These outcomes are in consonance with previous results such as Singh et al. (2007) for developed countries and Lerskullawat (2014) for developing countries. 


\begin{tabular}{|c|c|c|c|c|c|c|c|c|c|c|c|c|}
\hline $\begin{array}{c}\text { Descriptive } \\
\text { Statistics }\end{array}$ & BSDA & BSDS & CMDA & CMDS & FEFF & BMD & FLO & INT & LCCH & EXC & LASP & IEC \\
\hline Mean & 17.0830 & 0.8761 & 1.6005 & 14.0204 & 0.0653 & 7.2867 & -1.0425 & 14.0954 & 7248.346 & 96.2482 & 15964.01 & 19.1267 \\
\hline Median & 4.6799 & 0.9011 & 0.1213 & 2.9575 & 0.0530 & 2.6084 & -0.7119 & 13.5000 & 873.9359 & 114.5131 & 10873.77 & 11.3500 \\
\hline Max & 80.7425 & 1.2538 & 11.9829 & 92.9443 & 0.2570 & 33.4598 & -0.5838 & 26.7000 & 49304.08 & 305.9333 & 60952.95 & 73.1000 \\
\hline Min & 0.4064 & 0.5293 & 0.0019 & 0.1016 & 0.0061 & 0.4245 & -2.0771 & 6.0000 & 14.8000 & 1.0016 & 138.4656 & 2.1379 \\
\hline SD & 22.0318 & 0.1821 & 2.7706 & 21.2255 & 0.0489 & 8.7963 & 0.5451 & 3.8445 & 12925.44 & 79.0033 & 15117.83 & 17.8358 \\
\hline Skew & 1.3370 & -0.0952 & 2.0981 & 1.8704 & 1.1623 & 1.3965 & -0.8504 & 0.5224 & 2.1762 & 0.6121 & 0.7859 & 1.5410 \\
\hline Kurt & 3.3834 & 2.1794 & 6.8319 & 6.0643 & 4.6740 & 3.8826 & 1.9117 & 4.3081 & 6.688918 & 3.0420 & 2.8329 & 4.0263 \\
\hline J-Bera & 38.9199 & 3.7849 & 172.2183 & 124.7128 & 43.7663 & 45.7569 & 21.7458 & 14.9465 & 173.6090 & 8.0016 & 13.3241 & 56.2737 \\
\hline Prob & 0.0000 & 0.1507 & 0.0000 & 0.0000 & 0.0000 & 0.0000 & 0.0000 & 0.0006 & 0.0000 & 0.0183 & 0.0013 & 0.0000 \\
\hline Sum & 2186.626 & 112.1434 & 204.8697 & 1794.611 & 8.3618 & 932.6985 & $\begin{array}{c}- \\
133.443 \\
\end{array}$ & 1804.211 & 927788.3 & 12319.78 & 2043393 & 2448.221 \\
\hline SSD & 61645.94 & 4.2099 & 974.8960 & 57216.25 & 0.3040 & 9826.555 & 37.7341 & 1877.057 & $2.12 \mathrm{E}+10$ & 792673.0 & $2.90 \mathrm{E}+10$ & 40400.51 \\
\hline Obs & 128 & 128 & 128 & 128 & 128 & 128 & 128 & 128 & 128 & 128 & 128 & 128 \\
\hline
\end{tabular}

Note: BSDS - Bank Size, BSDA - Bank Activity, CMDS - Capital Market Size, CMDA - Capital Market Activity, FEFF - Financial Market
Financial Liberalization, INT - Interest Rate, EXC - Exchange Rate, CCH - Private Credits, ASP - Asset Prices, IEC - Inflation Expectations 


\begin{tabular}{c|c|c|c|c|c}
\multicolumn{7}{c}{ Table-2. Correlation matrix. } \\
\hline Variables & INT & CCH & EXC & ASP & IEC \\
\hline BSDS & -0.52757 & 0.218535 & -0.0555 & -0.03021 & 0.067763 \\
\hline BSDA & -0.41731 & 0.104568 & 0.413315 & -0.03981 & -0.36691 \\
\hline CMDS & -0.4678 & 0.006795 & 0.316772 & -0.06015 & -0.35624 \\
\hline CMDA & -0.41559 & 0.05645 & 0.306046 & 0.023556 & -0.32569 \\
\hline FEFF & -0.3408 & -0.05731 & 0.29849 & 0.031713 & -0.35213 \\
\hline BMD & -0.32884 & 0.057431 & 0.38578 & -0.0744 & -0.35968 \\
\hline FLO & -0.42133 & 0.423784 & 0.023033 & 0.04434 & -0.24251 \\
\hline
\end{tabular}

Table-3. Unit root test - zivot andrews and perron test.

\begin{tabular}{|c|c|c|c|c|}
\hline \multirow[t]{2}{*}{ Variables } & \multirow[t]{2}{*}{ Test } & \multicolumn{2}{|c|}{ Level } & \multirow[b]{2}{*}{ Decision } \\
\hline & & T-Stats & Break & \\
\hline \multirow[t]{2}{*}{ BSDS } & $\mathrm{ZA}$ & -3.3339 & $2011 Q^{2}$ & $\mathrm{I}(1)$ \\
\hline & Perron & -3.358 & $2011 Q 1$ & $\mathrm{I}(1)$ \\
\hline \multirow[t]{2}{*}{ BSDA } & $\mathrm{ZA}$ & -3.5094 & $2013 Q 1$ & $\mathrm{I}(1)$ \\
\hline & Perron & -4.8022 & $2013 Q 1$ & $\mathrm{I}(1)$ \\
\hline \multirow[t]{2}{*}{ CMDS } & $\mathrm{ZA}$ & -3.3086 & $2013 Q 1$ & $\mathrm{I}(1)$ \\
\hline & Perron & -4.0571 & $2013 Q 1$ & $\mathrm{I}(1)$ \\
\hline \multirow[t]{2}{*}{ CMDA } & $\mathrm{ZA}$ & -3.2429 & $2003 Q^{3}$ & $\mathrm{I}(1)$ \\
\hline & Perron & -3.7189 & $2013 Q 1$ & $\mathrm{I}(1)$ \\
\hline \multirow[t]{2}{*}{ FEFF } & $\mathrm{ZA}$ & -3.9923 & $2013 Q 1$ & $\mathrm{I}(1)$ \\
\hline & Perron & -4.2137 & $2013 Q 1$ & $\mathrm{I}(1)$ \\
\hline \multirow[t]{2}{*}{ BMD } & $\mathrm{ZA}$ & -3.4493 & $2013 Q^{1}$ & $\mathrm{I}(1)$ \\
\hline & Perron & -5.1869 & $2013 Q 1$ & $\mathrm{I}(1)$ \\
\hline \multirow[t]{2}{*}{ FLO } & $\mathrm{ZA}$ & -4.2539 & $1997 Q^{3}$ & $\mathrm{I}(1)$ \\
\hline & Perron & -4.6028 & $1997 \mathrm{Q} 1$ & $\mathrm{I}(1)$ \\
\hline \multirow[t]{2}{*}{ INT } & $\mathrm{ZA}$ & -4.1805 & $2004 Q 1$ & $\mathrm{I}(1)$ \\
\hline & Perron & -3.7267 & $2003 Q^{4}$ & $\mathrm{I}(1)$ \\
\hline \multirow[t]{2}{*}{$\mathrm{CCH}$} & $\mathrm{ZA}$ & -2.0832 & $2013 Q^{1}$ & $\mathrm{I}(1)$ \\
\hline & Perron & -1.1013 & $2013 Q_{1}$ & $\mathrm{I}(1)$ \\
\hline \multirow[t]{2}{*}{ EXC } & ZA & -1.5569 & 1999Q1 & $\mathrm{I}(1)$ \\
\hline & Perron & -1.646 & $2013 Q 1$ & $\mathrm{I}(1)$ \\
\hline \multirow[t]{2}{*}{$\mathrm{ASP}$} & $\mathrm{ZA}$ & -4.4876 & $2003 Q^{2}$ & $\mathrm{I}(1)$ \\
\hline & Perron & -5.0372 & $2008 Q 1$ & $\mathrm{I}(1)$ \\
\hline \multirow[t]{2}{*}{ IEC } & $\mathrm{ZA}$ & -5.4576 & 1996Q1 & $\mathrm{I}(\mathrm{O})$ \\
\hline & Perron & -5.637 & $1995 Q^{4}$ & $\mathrm{I}(\mathrm{O})$ \\
\hline
\end{tabular}

Note: The ZA critical value with intercept are $-5.34(1 \%),-4.93(5 \%)$ and $-4.58(10 \%)$. The Perron critical value with intercept are $-5.92(1 \%),-5.23(5 \%)$ and $-4.92(10 \%)$. ****, ** and ${ }^{*}$ denote significance at $1 \%, 5 \%$ and $10 \%$ levels, respectively.

Table-4. Bound test result.

\begin{tabular}{c|c|c|c|c|c}
\hline F-Statistic & Int Rate & Credit & Exc Rate & Asp & Exp \\
\hline Lower(5\%) & 3.79 & 3.79 & 3.79 & 3.79 & 3.79 \\
\hline Upper(5\%) & 4.85 & 4.85 & 4.85 & 4.85 & 4.85 \\
\hline BSDS & 13.75 & 1.92 & 0.87 & 0.98 & 6.78 \\
\hline BSDA & 14.14 & 4.95 & 1.08 & 1.25 & 5.11 \\
\hline CMDS & 14.72 & 1.85 & 1.32 & 16.44 & 5.11 \\
\hline CMDA & 14.63 & 1.83 & 1.19 & 1.79 & 6.67 \\
\hline FEFF & 15.43 & 1.97 & 1.06 & 6.05 & 6.33 \\
\hline BMD & 14.33 & 5.43 & 1.28 & 1.06 & 5.11 \\
\hline FLO & 14.65 & 1.27 & 0.93 & 1.09 & 3.73 \\
\hline
\end{tabular}

The interpretation of the cointegrating equation is that the coefficient has to be negative and its probability value has to be significant for there to be a movement to the long run. Based on the analysis, the adjustment speed towards equilibrium is approximately 37\%, meaning that it is adjusting at a pace of 37\% quarterly towards equilibrium. For the credit channel, the result showed that the size measure of the banking sector and its interaction term does not significantly affect the credit channel in the short run for Nigeria. However, the structural break date significantly influenced this channel. This implies that the rise in money supply, domestic credits to government and private sectors and investor confidence in the stock market due to its strong performance during the period led to key improvements in the credit channel of monetary policy. The error correction term however was in line with a priori since it has a negative sign and was statistically significant. These results are not in line with previous results such as Singh et al. (2007); Visco (2007) and Aysun et al. (2012) for developed countries and Claus and Smith (1999); Aysun et al. (2012); Lerskullawat (2014) for developing countries.

For exchange rate channel, the size measure of bank development does not significantly influence the exchange rate channel. However, when it interacts with the policy rate, it significantly improves the effect of bank size on exchange rate channel. Hence, this result confirms that the size measure of banks leads to an appreciation in exchange rate. This result is in line with theory since a bigger bank size leads to a higher level of financial intermediation and a better opportunity for banks to obtain loans even from international sources and for their product offerings to be available at the international market at favorable exchange rate. Therefore, developments in 
bank size can be used as a tool to improve exchange rate management, which in turn strengthens exchange rate channel in the short run, since exchange rate channel facilitates business and investments across borders.

For asset price channel, the lag of the dependent variable also significantly influences asset prices in the short term. Furthermore, bank size development significantly affects asset prices positively. The implication of this result is that banking sector development by size leads to a higher level of financial intermediation and thus, reduces over dependence of capital market firms sourcing funds internally since these firms can source funds externally by issuing equity or debt instruments at a lower funding and agency cost. Moreover, when the policy rate interacts with bank size development, it also significantly influences asset prices at $5 \%$ significance level. This result is in line with a priori, since a higher level of bank size implies a high level of financial intermediation and reduces over dependence of capital market firms sourcing funds internally since more funds can be generated by issuing equity or debt instruments in the short run. These outcomes are also in consonance with previous results such as Singh et al. (2007); Visco (2007) and Aysun et al. (2012) for developed countries and and Claus. and Smith (1999); Aysun et al. (2012); Lerskullawat (2014) for developing countries.

For inflation expectations channel, the results from Table 5 showed that banking sector development and its interaction with the policy rate does not influence inflation expectations in the short period. However, the structural break dates of first quarter 1991 and 1996 affected inflation expectations. This implies that the financial market deregulation policies of 1991 improved inflation expectations, while the exchange rate deregulation policy of 1996 significantly reduced inflation expectations in the short period. The error correction term however was in line with the theoretical expectation since it was significant with the appropriate sign.

In the long term, the results of the impact of banking sector development and its interaction term in Table 6 does not significantly improve interest rate channel. However, the policy rate significantly improved the interest rate channel of monetary policy in the long run. Therefore, a unit increase in monetary policy rate improves this channel by approximately 1.6 units. For inflation expectations channel, the result showed that bank size and its interaction term does not significantly influence inflation expectations in the long run. However, the financial market liberalization polices of 1991 significantly improved inflation expectations, while the deregulation policies of 1996 significantly reduced inflation expectations in the long run for Nigeria. The diagnostic test models have a very high Adjusted $\mathrm{R}^{2}$, which indicates our result is robust enough since it indicates that the independent variables greatly explained the dependent variable, while the serial correlation and homoscedasticity test showed that the models are not serially correlated and are homoscedastic.

Table-5. Short run result of the banking sector development by size.

\begin{tabular}{|c|c|c|c|c|c|}
\hline Variable & INT & $\mathrm{CCH}$ & $\overline{\text { EXC }}$ & ASP & IEC \\
\hline \multirow[t]{2}{*}{ Lag of Dependent Variable $(-1)$} & 0.3146 & & & 0.4959 & \\
\hline & $(0.0001)^{* * *}$ & & & $(0.0000)^{* * * *}$ & \\
\hline \multirow[t]{2}{*}{ Lag of Dependent Variable $(-2)$} & 0.2211 & & & & \\
\hline & $(0.0094)^{* * * *}$ & & & & \\
\hline \multirow[t]{2}{*}{$\mathrm{D}(\mathrm{BSDS} * \mathrm{MPR})$} & 1.0848 & -131.0 & 6.4817 & -3932 & 0.3727 \\
\hline & $(0.0179)^{* * *}$ & $(0.5664)$ & $(0.0010)^{* * * *}$ & $(0.0436)^{* * *}$ & $(0.6838)$ \\
\hline \multirow[t]{2}{*}{$\mathrm{D}$ (BSDS) } & -9.2031 & 2779 & -3.498221 & 69196 & -2.2378 \\
\hline & (0.1968) & $(0.4083)$ & $(0.8382)$ & $(0.0140)^{* * *}$ & $(0.8618)$ \\
\hline \multirow[t]{2}{*}{$\mathrm{D}(\mathrm{MPR})$} & -0.8100 & 76.79 & -4.355635 & & -0.1904 \\
\hline & $(0.0205)^{* * *}$ & $(0.7082)$ & $(0.0059)^{* * * *}$ & & (0.8134) \\
\hline \multirow[t]{2}{*}{$\mathrm{D}(\mathrm{MPR}(-3))$} & -0.2067 & & & & \\
\hline & $(0.0218)^{* * *}$ & & & & \\
\hline \multirow[t]{2}{*}{ DU_2005Q1 } & 0.3102 & & & & \\
\hline & $(0.6662)$ & & & & \\
\hline \multirow[t]{2}{*}{ DU_2011Q4 } & 0.2557 & & & & \\
\hline & $(0.7040)$ & & & & \\
\hline \multirow[t]{2}{*}{ DU_2013Q2 } & & 3508 & & & \\
\hline & & $(0.0009)^{* * *}$ & & & \\
\hline \multirow[t]{2}{*}{ DU_2008Q 2} & & & & 356.2 & \\
\hline & & & & $(0.6016)$ & \\
\hline \multirow[t]{2}{*}{$\mathrm{DU}_{-1991 \mathrm{Q}^{1}}$} & & & & & 6.0736 \\
\hline & & & & & $(0.0341)^{* * *}$ \\
\hline \multirow[t]{2}{*}{ DU_1996Q1 } & & & & & -10.5961 \\
\hline & & & & & $(0.0062)^{* *}$ \\
\hline \multirow[t]{2}{*}{$\operatorname{ECT}(-1)$} & -0.373889 & -0.0632 & 0.019717 & -0.031254 & -0.2503 \\
\hline & $(0.0000)^{* * * *}$ & $(0.0327)^{* *}$ & $(0.2174)$ & (0.1266) & $(0.0000)^{* * * *}$ \\
\hline
\end{tabular}

Note: $* * * * *$ and $*$ denote significance at $1 \%, 5 \%$ and $10 \%$ levels respectively.

For banking sector development by activity, the results in Table 7 showed that bank activity in the current period does not significantly affect interest rate channel; however, the previous quarter activity measure of banking sector development significantly affects interest rate channel. The interaction between bank activity and monetary policy showed an incomplete lower degree of pass-through for Nigeria. By implication, a higher activity value indicates improvements in banking sector activity in terms of deposits, savings and loan services. Therefore, this reduces the elasticity of demand for deposit and loans leading to a lower degree of interest rate pass-through.

For the credit channel, the previous lags of the dependent variable influenced the credit channel in the current period. Furthermore, the result showed that the third lag of bank activity measurement and the first lag of its 
interaction term significantly affect the credit channel in the short period for Nigeria. By implication, a higher activity value indicates improvements in banking sector activity in terms of services provided to customers, which will encourage deposits, savings and loan facilities and thus reduce the impact of monetary policy rate on the bank lending channel. This outcome is in consonance with previous results such as Singh et al. (2007); Visco (2007) and Aysun et al. (2012) for developed countries and Claus. and Smith (1999); Aysun et al. (2012); Lerskullawat (2014) for developing countries. Finally, the cointegrating equation and the structural break date significantly influenced this channel as earlier indicated under the size measure.

Table-6. Long run result of the banking sector development by size.

\begin{tabular}{|c|c|c|c|c|c|}
\hline Variable & INT & $\mathrm{CCH}$ & EXC & ASP & IEC \\
\hline \multirow[t]{2}{*}{ BSDS * MPR } & -0.6787 & -2073 & -10.82 & -125820 & 1.489091 \\
\hline & $(0.2782)$ & $(0.5720)$ & $(0.8620)$ & $(0.2120)$ & $(0.6784)$ \\
\hline \multirow[t]{2}{*}{ BSDS } & 4.0006 & 43977 & 177.42 & 2213945 & -8.9402 \\
\hline & $(0.6918)$ & $(0.4197)$ & $(0.8380)$ & $(0.1836)$ & $(0.8609)$ \\
\hline \multirow[t]{2}{*}{ MPR } & 1.554 & 1215 & 5.6657 & & -0.7606 \\
\hline & $(0.0056)^{* * * *}$ & $(0.7106)$ & $(0.9180)$ & & $(0.8114)$ \\
\hline \multirow[t]{2}{*}{ DU_2005Q1 } & 0.8297 & & & & \\
\hline & $(0.6726)$ & & & & \\
\hline \multirow[t]{2}{*}{ DU_2011Q4 } & 0.6839 & & & & \\
\hline & $(0.6986)$ & & & & \\
\hline \multirow[t]{2}{*}{ DU_2013Q2 } & & 55506 & & & \\
\hline & & $(0.0002)^{* * * *}$ & & & \\
\hline \multirow[t]{2}{*}{ DU_2008Q2 2} & & & & 11396 & \\
\hline & & & & (0.5223) & \\
\hline \multirow[t]{2}{*}{ DU_1991Q1 } & & & & & 24.26 \\
\hline & & & & & $(0.0160)^{* * *}$ \\
\hline \multirow[t]{2}{*}{ DU_1996Q1 } & & & & & -42.3323 \\
\hline & & & & & $(0.0006)^{* * * *}$ \\
\hline \multirow[t]{2}{*}{$\mathrm{C}$} & -4.5412 & -25874 & -130.3 & 19339 & 28.724504 \\
\hline & $(0.6162)$ & $(0.6171)$ & $(0.8780)$ & $(0.0860)$ & $(0.5528)$ \\
\hline Adj. $\mathrm{R}^{2}$ & 0.8914 & 0.9758 & 0.9833 & 0.9718 & 0.8216 \\
\hline Serial Correlation & 0.2945 & 0.0992 & 0.2283 & 0.5739 & 0.6021 \\
\hline Heteroscedasticity & 0.0565 & 0.9381 & 0.8584 & 0.2017 & 0.8898 \\
\hline
\end{tabular}

Table-7. Short run result of the banking sector development by activity.

\begin{tabular}{|c|c|c|c|c|c|}
\hline Variable & INT & $\mathrm{CCH}$ & EXC & ASP & IEC \\
\hline \multirow{2}{*}{ Lag of Dependent Variable $(-1)$} & 0.3025 & -0.0585 & & 0.5769 & \\
\hline & $(0.0003)^{* * *}$ & $(0.5048)$ & & $(0.0000)^{* * *}$ & \\
\hline \multirow{2}{*}{ Lag of Dependent Variable (-2) } & 0.1722 & -0.1708 & & & \\
\hline & $(0.0471)^{* *}$ & $(0.0545)^{*}$ & & & \\
\hline \multirow{2}{*}{$\mathrm{D}(\mathrm{BSDA} * \mathrm{MPR})$} & 0.0012 & 1.8679 & -0.0116 & -17.2671 & -0.0027 \\
\hline & $(0.7590)$ & $(0.6712)$ & $(0.3427)$ & $(0.1696)$ & $(0.7567)$ \\
\hline \multirow[t]{2}{*}{$\mathrm{D}(\mathrm{BSDA}(-1) * \operatorname{MPR}(-1))$} & 0.0072 & 7.7121 & & & \\
\hline & $(0.0721)^{*}$ & $(0.0870)^{*}$ & & & \\
\hline \multirow[t]{2}{*}{$\mathrm{D}(\mathrm{BSDA}(-2) * \mathrm{MPR}(-2))$} & 0.0025 & & & & \\
\hline & $(0.0776)^{*}$ & & & & \\
\hline \multirow[t]{2}{*}{$\mathrm{D}(\mathrm{BSDA})$} & -0.0391 & 61.6602 & 0.0906 & 304.01 & 0.0342 \\
\hline & $(0.5411)$ & $(0.3994)$ & $(0.5745)$ & $(0.0502)^{*}$ & $(0.7673)$ \\
\hline \multirow[t]{2}{*}{$\mathrm{D}(\operatorname{BSDA}(-1))$} & -0.1325 & & & & \\
\hline & $(0.0371)^{* *}$ & & & & \\
\hline \multirow[t]{2}{*}{$\mathrm{D}(\mathrm{BSDA}(-3))$} & & 67.6776 & & & \\
\hline & & $(0.0140)^{* * *}$ & & & \\
\hline \multirow[t]{2}{*}{$\mathrm{D}(\mathrm{MPR})$} & 0.0109 & -22.9725 & 0.3691 & & 0.1865 \\
\hline & $(0.9110)$ & $(0.7377)$ & $(0.3164)$ & & $(0.4706)$ \\
\hline \multirow[t]{2}{*}{$\mathrm{D}(\mathrm{MPR}(-3))$} & -0.2035 & & & & \\
\hline & $(0.0265)^{* *}$ & & & & \\
\hline \multirow[t]{2}{*}{ DU_2005Q1 } & 0.2725 & & & & \\
\hline & $(0.7097)$ & & & & \\
\hline \multirow[t]{2}{*}{ DU_2011Q4 } & 0.7964 & & & & \\
\hline & $(0.2854)$ & & & & \\
\hline \multirow[t]{2}{*}{ DU_2013Q2 } & & 8801 & & 579.45 & \\
\hline & & $(0.0000)^{* * * *}$ & & $(0.5157)$ & \\
\hline \multirow[t]{2}{*}{ DU_2008Q3 } & & & & 664.26 & \\
\hline & & & & $(0.3875)$ & \\
\hline \multirow[t]{2}{*}{ DU_1996Q1 } & & & & & -5.1165 \\
\hline & & & & & $(0.0143)^{* * *}$ \\
\hline \multirow[t]{2}{*}{$\operatorname{ECT}(-1)$} & -0.3818 & -0.1667 & 0.0258 & -0.0484 & -0.1938 \\
\hline & $(0.0000)^{* * * *}$ & $(0.0000)^{* * * *}$ & $(0.0711)^{*}$ & $(0.0135)^{* * *}$ & $(0.0002)^{* * * *}$ \\
\hline
\end{tabular}


For exchange rate channel, the activity measure of banks does not significantly influence the exchange rate channel. This result was also confirmed when the activity measure interacted with the policy rate. For asset price channel, the lag of the dependent variable also significantly influenced asset prices in the short term. Furthermore, the activity measure of banks also influences asset prices positively. The implication of this result is that banking sector development by activity leads to higher levels of financial intermediation and thus, reduces over dependence of capital market firms sourcing funds internally since these firms can source funds externally by issuing equity or debt instruments at a lower funding and agency cost. For inflation expectations channel, the results from Table 7 showed that banking sector development by activity and its interaction with the policy rate does not significantly affect inflation expectations in the short period. However, the structural break date of 1996 significantly affected inflation expectations. This implies that the financial market deregulation policies of 1996 significantly reduced inflation expectations in the near term. The error correction term was also in line with theoretical expectation.

In the long term, the interaction term as displayed in Table 8 significantly weakened the interest rate channel. Furthermore, the policy rate significantly improved the interest rate channel of monetary policy in the long run. This result is in line with a priori since the interaction term is theoretically expected to weaken interest rates. By implication, a higher activity value indicates improvements in banking sector activity in terms of services provided to customers, leading to lesser levels of interest rate pass-through. For inflation expectations channel, the result showed that banking sector development by activity and its interaction term does not significantly influence inflation expectations in the long term. However, the structural break date of 1996 significantly affected inflation expectations. This implies that the financial market deregulation policies of 1996 significantly reduced inflation expectations in the long run for Nigeria. For the credit channel of monetary policy, the results of banking sector development by activity and its interaction term where insignificant on the credit channel. Furthermore, the structural break date significantly influenced this channel.

Table-8. Long run result of the banking sector development by activity.

\begin{tabular}{|c|c|c|c|c|c|}
\hline Variable & INT & $\mathrm{CCH}$ & EXC & ASP & IEC \\
\hline \multirow[t]{2}{*}{ BSDA * MPR } & -0.0142 & -20.4102 & 0.45 & -964.96 & -0.0139 \\
\hline & $(0.0352)^{* *}$ & $(0.1652)$ & $(0.3570)$ & $(0.0552)^{*}$ & $(0.7576)$ \\
\hline \multirow[t]{2}{*}{ BSDA } & 0.1442 & 316.77 & -3.51 & 13817 & 0.1765 \\
\hline & $(0.1212)$ & $(0.1070)$ & $(0.5820)$ & $(0.0391)^{* *}$ & $(0.7684)$ \\
\hline \multirow[t]{2}{*}{ MPR } & 1.3069 & -137.78 & -14.3 & & 0.9628 \\
\hline & $(0.0000)^{* * * *}$ & $(0.7381)$ & $(0.3180)$ & & $(0.4776)$ \\
\hline \multirow[t]{2}{*}{ DU_2005Q1 } & 0.7138 & & & & \\
\hline & $(0.7153)$ & & & & \\
\hline \multirow[t]{2}{*}{ DU_2011Q4 } & 2.0861 & & & & \\
\hline & $(0.2566)$ & & & & \\
\hline \multirow[t]{2}{*}{ DU_2013Q2 } & & 52782 & & 11975 & \\
\hline & & $(0.0000) * * *$ & & $(0.5189)$ & \\
\hline \multirow[t]{2}{*}{ DU_2008Q2 } & & & & 13728 & \\
\hline & & & & (0.3339) & \\
\hline \multirow[t]{2}{*}{ DU_1996Q1 } & & & & & -26.41 \\
\hline & & & & & $(0.0033)^{* *}$ \\
\hline \multirow[t]{2}{*}{$\mathrm{C}$} & -5.4433 & 2889 & 170.55 & 12839 & 23.91 \\
\hline & $(0.1284)$ & $(0.6637)$ & $(0.4240)$ & $(0.0277)^{* *}$ & $(0.2796)$ \\
\hline Adj. $\mathrm{R}^{2}$ & 0.8846 & 0.9783 & 0.9818 & 0.9728 & 0.8164 \\
\hline Serial Correlation & 0.2619 & 0.1484 & 0.5381 & 0.9897 & 0.4356 \\
\hline Heteroscedasticity & 0.5324 & 0.9924 & 0.9181 & 0.2017 & 0.8360 \\
\hline
\end{tabular}

Note: ***,** and $*$ denote significance at $1 \%, 5 \%$ and $10 \%$ levels, respectively

\subsection{Capital Market Development and Monetary Transmission Mechanism}

The analyses of the capital market and monetary transmission mechanism were informed from three separate analyses which are the size measure, activity measure and efficiency measure. The first discussion borders around the size measure. From Table 9, the previous lags of the dependent variable influenced current interest rate, while the third lag of monetary policy rate also influenced interest rates positively. However, the interest rate channel result proved that capital market size and its interaction term does not significantly influence interest rate channel. The cointegrating equation was however significant, implying that $34 \%$ of the short run errors are corrected in the long term. For the credit channel, the result showed that the size measure of capital market development and its interaction term does not influence the credit channel in the near term. However, the structural break date significantly influenced this channel. The error correction term was also in line with theoretical expectation. For exchange rate channel, capital market size does not significantly influence the exchange rate channel. This result was also confirmed when the size measure interacted with the policy rate. For inflation expectations channel, the results from Table 9 showed that capital market size and its joint interaction with monetary policy does not significantly affect inflation expectations in the near term. However, the structural break date of 1996 significantly affected inflation expectations. This implies that the financial market deregulation policies of 1996 significantly reduced inflation expectations in the near term. The error correction term was also in line with theoretical expectation.

For asset price channel, the lag of the dependent variable significantly influenced asset prices in the near term. Furthermore, the size measure of capital market development significantly influenced asset prices. The implication of this result is that capital market size leads to a higher degree of financial disintermediation and thus, reduces over dependence of capital market firms sourcing funds internally since these firms can source funds externally by issuing equity or debt instruments at a lower funding and agency cost. This result is in line with a priori, since a greater capital market size indicates higher levels of disintermediation. The error correction term even though 
negative, was statistically insignificant. This means that a movement to the long term may not be possible since the two conditions for a movement to occur was not satisfied. The results of the activity and efficiency measure of capital market development were also in line with the size measure of capital market development in the short run as verified from Tables 11 and 13 (see Appendix).

Table-9. Size measure of capital market development short run result.

\begin{tabular}{|c|c|c|c|c|c|}
\hline Variable & INT & $\mathrm{CCH}$ & EXC & ASP & IEC \\
\hline \multirow[t]{2}{*}{ Lag of Dependent Variable $(-1)$} & 0.3124 & & & 0.2757 & \\
\hline & $(0.0002)^{* * * *}$ & & & $(0.0021)^{* * *}$ & \\
\hline \multirow[t]{2}{*}{ Lag of Dependent Variable (-2) } & 0.1508 & & & & \\
\hline & $(0.0808)^{*}$ & & & & \\
\hline \multirow[t]{2}{*}{$\mathrm{D}(\mathrm{CMDS} * \mathrm{MPR})$} & -0.0019 & -1.4487 & -0.0136 & -44.66 & -0.0036 \\
\hline & $(0.4649)$ & $(0.6092)$ & $(0.3654)$ & $(0.0000) * * *$ & $(0.7368)$ \\
\hline \multirow[t]{2}{*}{$\mathrm{D}(\mathrm{CMDS}(-2) * \operatorname{MPR}(-2))$} & & & & -26.27 & \\
\hline & & & & $(0.0089)^{* * *}$ & \\
\hline \multirow[t]{2}{*}{$\mathrm{D}(\mathrm{CMDS}(-3) * \operatorname{MPR}(-3))$} & & & & -8.7837 & \\
\hline & & & & $(0.0002) * * *$ & \\
\hline \multirow[t]{2}{*}{$\mathrm{D}$ (CMDS) } & 0.0081 & 23.3271 & 0.0713 & 693.71 & 0.0361 \\
\hline & $(0.8119)$ & $(0.4935)$ & $(0.6835)$ & $(0.0000)^{* * *}$ & $(0.7716)$ \\
\hline \multirow[t]{2}{*}{$\mathrm{D}(\mathrm{CMDS}(-1))$} & & & & -227.61 & \\
\hline & & & & $(0.0594)^{*}$ & \\
\hline \multirow[t]{2}{*}{$\mathrm{D}(\mathrm{CMDS}(-2))$} & & & & 250.35 & \\
\hline & & & & $(0.0277)^{* * *}$ & \\
\hline \multirow[t]{2}{*}{$\mathrm{D}(\mathrm{MPR})$} & 0.0279 & -24.7336 & 0.2327 & 5.8013 & 0.1699 \\
\hline & $(0.7583)$ & $(0.7031)$ & $(0.4979)$ & $(0.9169)$ & $(0.4789)$ \\
\hline \multirow[t]{2}{*}{$\mathrm{D}(\mathrm{MPR}(-3))$} & -0.1639 & & & & \\
\hline & $(0.0697)^{*}$ & & & & \\
\hline \multirow[t]{2}{*}{ DU_2005Q1 } & 0.7742 & & & & \\
\hline & $(0.3047)$ & & & & \\
\hline \multirow[t]{2}{*}{ DU_2011Q4 } & -0.1332 & & & & \\
\hline & $(0.8561)$ & & & & \\
\hline \multirow[t]{2}{*}{ DU_2013Q2 } & & 3574 & & & \\
\hline & & $(0.0010)^{* * * *}$ & & & \\
\hline \multirow[t]{2}{*}{ DU_2009Q3 } & & & & 771.55 & \\
\hline & & & & $(0.1051)$ & \\
\hline \multirow[t]{2}{*}{ DU_1996Q1 } & & & & & -5.0179 \\
\hline & & & & & $(0.0149)^{* *}$ \\
\hline \multirow[t]{2}{*}{$\operatorname{ECT}(-1)$} & -0.3400 & -0.0614 & 0.0259 & -0.0087 & -0.1941 \\
\hline & $(0.0000)^{* * * *}$ & $(0.0387)^{* * *}$ & $(0.0639)^{*}$ & $(0.6224)$ & $(0.0002)^{* * * *}$ \\
\hline
\end{tabular}

Note: $* * * * *$ and $*$ denote significance at $1 \%, 5 \%$ and $10 \%$ levels, respectively.

Table-10. Size measure of capital market development long run result.

\begin{tabular}{|c|c|c|c|c|c|}
\hline Variable & INT & $\mathrm{CCH}$ & EXC & ASP & IEC \\
\hline \multirow[t]{2}{*}{ CMDS * MPR } & -0.0057 & -23.577 & 0.5268 & -3537 & -0.0185 \\
\hline & $(0.4617)$ & $(0.6219)$ & $(0.3582)$ & $(0.6585)$ & $(0.7381)$ \\
\hline \multirow[t]{2}{*}{ CMDS } & 0.0237 & 379.64 & -2.753 & 83199 & 0.1861 \\
\hline & $(0.8112)$ & $(0.5119)$ & $(0.6775)$ & $(0.6369)$ & $(0.7730)$ \\
\hline \multirow[t]{2}{*}{ MPR } & 1.1971 & -402.53 & -8.9903 & 670.12 & 0.8756 \\
\hline & $(0.0000)^{* * *}$ & $(0.7013)$ & $(0.4752)$ & $(0.9269)$ & $(0.4869)$ \\
\hline \multirow[t]{2}{*}{ DU_2005Q1 } & 2.2769 & & & & \\
\hline & $(0.3346)$ & & & & \\
\hline \multirow[t]{2}{*}{ DU_2011Q4 } & -0.3917 & & & & \\
\hline & $(0.8576)$ & & & & \\
\hline \multirow[t]{2}{*}{ DU_2013Q2 } & & 58160 & & & \\
\hline & & $(0.0003)^{* * * *}$ & & & \\
\hline \multirow[t]{2}{*}{ DU_2009Q3 } & & & & 89124 & \\
\hline & & & & $(0.5747)$ & \\
\hline \multirow[t]{2}{*}{ DU_1996Q1 } & & & & & -25.8566 \\
\hline & & & & & $(0.0033)^{* * * *}$ \\
\hline \multirow[t]{2}{*}{$\mathrm{C}$} & -3.9144 & 8844 & 82.7958 & 16074 & 25.27 \\
\hline & $(0.2941)$ & $(0.5950)$ & $(0.6821)$ & $(0.8609)$ & $(0.2217)$ \\
\hline Adj. $\mathrm{R}^{2}$ & 0.8808 & 0.9758 & 0.9819 & 0.9833 & 0.8164 \\
\hline Serial Correlation & 0.3844 & 0.6726 & 0.6206 & 0.2764 & 0.4293 \\
\hline Heteroscedasticity & 0.0742 & 0.9303 & 0.9161 & 0.0069 & 0.8354 \\
\hline
\end{tabular}

In the long term, the interaction between monetary policy and capital market size were insignificant as confirmed in Table 10. However, the signs confirmed the a priori expectation between the variables in the long run. The policy rate significantly improved interest rate in the long term. For inflation expectations channel, the result showed that capital market size and its interaction term does not significantly influence inflation expectations in the long run. Despite the insignificant result, the result still confirms the positive relationship between capital 
market sector by size measure and inflation expectations in the long run. However, the structural break date of 1996 significantly affected inflation expectations. This implies that the financial market deregulation policies of 1996 significantly reduced inflation expectations in the long run for Nigeria. The long run results of the activity and efficiency measure of capital market development were also in line with the results earlier generated on the size measure of capital market development as verified in Tables 12 and 14 (see Appendix).

\subsection{Bond Market Development and Monetary Transmission Mechanism}

From Table 15, the previous lags of the dependent variable influenced interest rates in the current period, while the third lag of monetary policy also influenced interest rates. The interest rate channel result proved that bond market development and its interaction term significantly influence interest rate. Furthermore, the interaction term confirms the positive expectation between bond market development and interest rate channel in the near term. By implication, a rise in this measure depicts improvements in fund services available to banks within the financial system, thereby leading to an improvement in banks risk diversification and liquidity, thereby strengthening interest rate channel in the short term. This outcome follows a priori on the relationship between the two variables. Furthermore, the coefficient of the adjustment speed is approximately $39 \%$, meaning that it is adjusting at a pace of $39 \%$ quarterly towards equilibrium.

For the credit channel, the second lag of the dependent variable also significantly influenced the credit channel. Furthermore, the first and third lag of bond market development and first lag of the interaction term significantly influenced the credit channel in the near term. By implication, improved developments within the equity and bond space leads to better prospects to invest in new security instruments and consequently, improved diversification of assets, hence, strengthening the credit channel in the near term. Furthermore, the structural break date significantly influenced this channel. The error correction term was also in line with theoretical expectation. For exchange rate channel, bond market development does not significantly influence the exchange rate channel. This result was also confirmed when bond market development interacted with the policy rate.

\begin{tabular}{|c|c|c|c|c|c|}
\hline Variable & INT & $\mathrm{CCH}$ & EXC & ASP & IEC \\
\hline \multirow[t]{2}{*}{ Lag of Dependent Variable $(-1)$} & 0.3046 & -0.0612 & & 0.5406 & \\
\hline & $(0.0003)^{* * * *}$ & $(0.4814)$ & & $(0.0000)^{* * *}$ & \\
\hline \multirow[t]{2}{*}{ Lag of Dependent Variable $(-2)$} & 0.1724 & -0.1686 & & & \\
\hline & $(0.0477)^{* *}$ & $(0.0547)^{*}$ & & & \\
\hline \multirow[t]{2}{*}{$\mathrm{D}\left(\mathrm{BMD}^{*} \mathrm{MPR}\right)$} & 0.0061 & -1.6973 & -0.0255 & -57.327 & -0.0063 \\
\hline & $(0.6038)$ & $(0.8924)$ & $(0.4565)$ & $(0.1300)$ & $(0.7972)$ \\
\hline \multirow[t]{2}{*}{$\mathrm{D}(\mathrm{BMD}(-1) * \operatorname{MPR}(-1))$} & 0.0199 & 40.8191 & & & \\
\hline & $(0.0835)^{*}$ & $(0.0144)^{* *}$ & & & \\
\hline \multirow[t]{2}{*}{$\mathrm{D}(\mathrm{BMD}(-2) * \operatorname{MPR}(-2))$} & 0.0068 & -13.4204 & & & \\
\hline & $(0.0422)^{*}$ & $(0.3919)$ & & & \\
\hline \multirow[t]{2}{*}{$\mathrm{D}(\mathrm{BMD}(-3) * \mathrm{MPR}(-3))$} & & -19.0588 & & & \\
\hline & & $(0.1443)$ & & & \\
\hline \multirow[t]{2}{*}{$\mathrm{D}(\mathrm{BMD})$} & -0.1692 & 277.1392 & 0.1808 & 882.959 & 0.0850 \\
\hline & $(0.3919)$ & $(0.2248)$ & $(0.7014)$ & $(0.0657)^{*}$ & $(0.8018)$ \\
\hline \multirow[t]{2}{*}{$\mathrm{D}(\mathrm{BMD}(-1))$} & -0.3708 & -615.695 & & 54.729 & \\
\hline & $(0.0585)^{*}$ & $(0.0405)^{* *}$ & & $(0.5153)$ & \\
\hline \multirow[t]{2}{*}{$\mathrm{D}(\mathrm{BMD}(-2))$} & & 218.712 & & -131.111 & \\
\hline & & $(0.4500)$ & & $(0.1147)$ & \\
\hline \multirow[t]{2}{*}{$\mathrm{D}(\mathrm{BMD}(-3))$} & & 509.958 & & -149.986 & \\
\hline & & $(0.0327)^{* *}$ & & $(0.0687)^{*}$ & \\
\hline \multirow[t]{2}{*}{$\mathrm{D}(\mathrm{MPR})$} & 0.0075 & 49.670 & 0.3727 & -50.8251 & 0.1866 \\
\hline & $(0.9419)$ & $(0.5249)$ & $(0.3466)$ & $(0.5181)$ & $(0.5020)$ \\
\hline \multirow[t]{2}{*}{$\mathrm{D}(\mathrm{MPR}(-3))$} & -0.2210 & & & & \\
\hline & $(0.0160) * *$ & & & & \\
\hline \multirow[t]{2}{*}{ DU_2005Q1 } & 0.1002 & & & & \\
\hline & $(0.8939)$ & & & & \\
\hline \multirow[t]{2}{*}{ DU_2011Q4 } & 1.0301 & & & & \\
\hline & $(0.1945)$ & & & & \\
\hline \multirow[t]{2}{*}{ DU_2013Q2 } & & 10190 & & & \\
\hline & & $(0.0000)^{* * * *}$ & & & \\
\hline \multirow[t]{2}{*}{ DU_2008Q2 } & & & & -435.340 & \\
\hline & & & & $(0.6077)$ & \\
\hline \multirow[t]{2}{*}{ DU_2012Q4 } & & & & 2093.44 & \\
\hline & & & & $(0.0417)^{* * *}$ & \\
\hline \multirow[t]{2}{*}{ DU_1996Q1 } & & & & & -5.1502 \\
\hline & & & & & $(0.0134)^{* * *}$ \\
\hline \multirow[t]{2}{*}{$\operatorname{ECT}(-1)$} & -0.3942 & -0.1901 & 0.0257 & -0.0488 & -0.1938 \\
\hline & $(0.0000)^{* * * *}$ & $(0.0000)^{* * * *}$ & $(0.0693)^{*}$ & $(0.0447)^{* * *}$ & $(0.0002)^{* * * *}$ \\
\hline
\end{tabular}

Note: ${ }^{* * *},{ }^{* *}$ and ${ }^{*}$ denote significance at $1 \%, 5 \%$ and $10 \%$ levels, respectively. 
For asset price channel, the lag of the dependent variable significantly influenced asset prices in the short run. Furthermore, bond market development and its third lag influenced asset prices. The implication of this result is that bond market development improved equity and bond market, and this led to better prospects to invest in new security instruments and consequently, improved asset prices, thereby improving the performance of the capital market. Also, the break date of 2012 fourth quarter significantly improved asset prices. Finally, the error correction term as expected follows a priori expectation. For inflation expectations channel, the results from Table 15 showed that bond market development and its interaction with monetary policy does not influence inflation expectations in the near term. However, the structural break date of 1996 significantly affected inflation expectations. This implies that the financial market deregulation policies of 1996 significantly reduced inflation expectations in the near term. The error correction term was also in line with a priori.

In the long term as presented in Table 16, the result of bond market development, monetary policy and their interaction were significant on interest rate channel. By implication, a rise in this measure depicts improved avenues to access funds within the financial system, thereby leading to an improvement in banks risk diversification and liquidity. Consequently, the interest rate channel is being strengthened in the long term for Nigeria. This result is in line with the theoretical expectation. For the credit channel, bond market development significantly influenced the credit channel in the near term with the correct sign. By implication, improved developments within the equity and bond space leads to improved avenues to invest in new security instruments and consequently, improved diversification of assets, hence, strengthening the credit channel in the long term. These results correspond with earlier works like Singh et al. (2007); Visco (2007) and Aysun et al. (2012) for developed countries and Claus. and Smith (1999); Aysun et al. (2012); Lerskullawat (2014) for developing countries. Furthermore, the structural break date significantly influenced this channel.

For inflation expectations channel, the result showed that bond market development and its interaction term does not significantly influence inflation expectations in the near term. However, the structural break date of 1996 significantly affected inflation expectations. This implies that the financial market deregulation policies of 1996 significantly reduced inflation expectations in the long run for Nigeria.

Table-16. Bond market development long run result.

\begin{tabular}{|c|c|c|c|c|c|}
\hline Variable & INT & $\mathrm{CCH}$ & EXC & ASP & IEC \\
\hline \multirow[t]{2}{*}{ BMD* MPR } & -0.0456 & -55.9741 & 0.9912 & -3078.43 & -0.0323 \\
\hline & $(0.0204)^{* * *}$ & $(0.1312)$ & $(0.4625)$ & $(0.0874)^{*}$ & $(0.7977)$ \\
\hline \multirow[t]{2}{*}{ BMD } & 0.5116 & 1015.5 & -7.0366 & 47563.88 & 0.4386 \\
\hline & $(0.0690)^{*}$ & $(0.0458)^{* *}$ & $(0.7029)$ & $(0.0728)^{*}$ & $(0.8025)$ \\
\hline \multirow[t]{2}{*}{ MPR } & 1.3858 & 261.31 & -14.505 & -1041.9 & 0.9628 \\
\hline & $(0.0000)^{* * * *}$ & $(0.5238)$ & $(0.3416)$ & $(0.4613)$ & $(0.5077)$ \\
\hline \multirow[t]{2}{*}{ DU_2005Q1 } & 0.2541 & & & & \\
\hline & $(0.8946)$ & & & & \\
\hline \multirow[t]{2}{*}{ DU_2011Q4 } & 2.6129 & & & & \\
\hline & $(0.1619)$ & & & & \\
\hline \multirow[t]{2}{*}{ DU_2013Q2 } & & 53607 & & & \\
\hline & & $(0.0000)^{* * * *}$ & & & \\
\hline \multirow[t]{2}{*}{ DU_2008Q2 } & & & & -8924.4 & \\
\hline & & & & $(0.6443)$ & \\
\hline \multirow[t]{2}{*}{ DU_2012Q4 } & & & & 42915 & \\
\hline & & & & $(0.1103)$ & \\
\hline \multirow[t]{2}{*}{ DU_1996Q1 } & & & & & -26.5793 \\
\hline & & & & & $(0.0030)^{* * * *}$ \\
\hline \multirow[t]{2}{*}{$\mathrm{C}$} & -6.4641 & -4259.5 & 165.975 & 30564 & 23.9454 \\
\hline & $(0.0759)^{*}$ & $(0.5264)$ & $(0.4674)$ & $(0.1613)$ & $(0.3074)$ \\
\hline Adj. $R^{2}$ & 0.8866 & 0.9788 & 0.9818 & 0.9727 & 0.8163 \\
\hline Serial Correlation & 0.3104 & 0.1047 & 0.5439 & 0.7017 & 0.4341 \\
\hline Heteroscedasticity & 0.6217 & 0.9532 & 0.9186 & 0.2017 & 0.8349 \\
\hline
\end{tabular}

Note: ******* and ${ }^{*}$ denote significance at $1 \%, 5 \%$ and $10 \%$ levels, respectively.

\subsection{Financial Market Liberalization and Monetary Transmission Mechanism}

From Table 17, the previous lag of the dependent variable influenced interest rates in the present period, while the policy rate also influenced interest rates. The interest rate channel result proved that financial market liberalization and the third lag of the interaction term significantly influenced interest rate channel. Furthermore, the interaction term confirms the positive expectation between the interaction term and interest rate channel, while the result also confirms the negative relationship between financial liberalization and interest rate channel in the near term. By implication, the relaxation of financial market restrictions will improve business activities through investments in capital market instruments. This implies more avenues for banks to source for funding thereby weakening interest rate channel. However, for the interaction term, the liberalization in capital account and banking sector deregulation leads to improvements within foreign exchange management and the credit risk process, improving banks' ability to provide liquidity within the financial system.

This result provides the impetus when financial market liberalization interacts with the policy rate. The results of financial liberalization and the interaction term are in line with a priori since this measure can have a positive or negative outcome on interest rate in the near term. The cointegrating equation's interpretation is that its coefficient has to be negative and its probability value has to be significant for there to be a movement to the long term. Based on the analysis, the coefficient of the adjustment speed is approximately $38 \%$, meaning that it is adjusting at a pace of $38 \%$ quarterly towards equilibrium. Therefore, it can be concluded that the error correction term is in line with a priori expectation.

For the credit channel, financial market liberalization and its interaction term does not significantly influence the credit channel in the near term. For exchange rate channel, the result is also insignificant, and this shows that 
financial market liberalization and its interaction term does not improve the exchange rate process. By implication, financial market liberalization and its interaction term has not improved the credit risk and foreign exchange process for Nigeria in the near term. The asset price channel also followed suite since financial market liberalization and its interaction with monetary policy were not found to significantly improve the asset price channel. By implication, the relaxation of financial market restrictions did not improve business activities within the capital market space. The error correction terms were also statistically insignificant for the three channels of monetary policy. For inflation expectations channel, the results from Table 17 showed that the third lag of financial market liberalization influenced inflation expectations in the short run. However, when financial liberalization interacted with the policy rate, the result became insignificant. By implication, the relaxation of market restrictions improved business activities within the financial system via issuing capital market securities and investments. This reduces inflation expectations in the near term for Nigeria. The error correction term was also in line with theoretical expectation.

Finally, Table 18 presented the long-term result. For interest rate channel, the result of financial market liberalization, the policy rate and their interaction term were significant. By implication, the liberalization in capital account and banking sector deregulation leads to improvements in the credit risk process and foreign exchange management, and this improves the ability of banks in providing financial system liquidity, thus strengthening interest rate channel in the long term. However, when the policy rate interacts with financial market liberalization, the implication of the result is that the removal of restrictions within the financial system will improve business activities through investments in financial securities. This implies more avenues for banks to source for funding thereby weakening interest rate channel in the long term for Nigeria. Finally, the other channels were not cointegrated as verified through the bound test procedure, which implies that their long run results were insignificant for Nigeria.

Table-17. Financial liberalization short run result.

\begin{tabular}{|c|c|c|c|c|c|}
\hline Variable & INT & $\mathrm{CCH}$ & EXC & ASP & IEC \\
\hline \multirow[t]{2}{*}{ Lag of Dependent Variable $(-1)$} & 0.2889 & & & 0.5082 & \\
\hline & $(0.0004)^{* * * *}$ & & & $(0.0000)^{* * *}$ & \\
\hline \multirow[t]{2}{*}{$\mathrm{D}(\mathrm{FLO} * \mathrm{MPR})$} & 0.1324 & -24.8998 & 0.2007 & 454.608 & -0.1011 \\
\hline & $(0.1294)$ & $(0.7879)$ & $(0.2253)$ & $(0.7518)$ & $(0.3894)$ \\
\hline \multirow[t]{2}{*}{$\mathrm{D}(\mathrm{FLO}(-1) * \operatorname{MPR}(-1))$} & -0.0013 & & & & \\
\hline & $(0.9869)$ & & & & \\
\hline \multirow[t]{2}{*}{$\mathrm{D}(\mathrm{FLO}(-2) * \operatorname{MPR}(-2))$} & 0.0556 & & & & \\
\hline & $(0.4448)$ & & & & \\
\hline \multirow[t]{2}{*}{$\mathrm{D}(\mathrm{FLO}(-3) * \operatorname{MPR}(-3))$} & 0.1300 & & & & \\
\hline & $(0.0201)^{* *}$ & & & & \\
\hline \multirow[t]{2}{*}{$\mathrm{D}(\mathrm{FLO})$} & -4.6347 & 640.015 & 2.8736 & -8065 & 12.6140 \\
\hline & $(0.0621)^{*}$ & $(0.6535)$ & $(0.7952)$ & $(0.7533)$ & $(0.2486)$ \\
\hline \multirow[t]{2}{*}{$\mathrm{D}(\mathrm{FLO}(-1))$} & 0.6838 & & & & 9.6719 \\
\hline & $(0.8597)$ & & & & $(0.3788)$ \\
\hline \multirow[t]{2}{*}{$\mathrm{D}(\mathrm{FLO}(-2))$} & -3.3224 & & & & 15.4808 \\
\hline & $(0.1680)$ & & & & $(0.1571)$ \\
\hline \multirow[t]{2}{*}{$\mathrm{D}(\mathrm{FLO}(-3))$} & & & & & -39.4902 \\
\hline & & & & & $(0.0004)^{* * *}$ \\
\hline \multirow[t]{2}{*}{$\mathrm{D}(\mathrm{MPR})$} & 0.1897 & -45.1689 & 0.5479 & -24.0212 & 0.0181 \\
\hline & $(0.0525)^{*}$ & $(0.6964)$ & $(0.1355)$ & $(0.7529)$ & $(0.9472)$ \\
\hline \multirow[t]{2}{*}{$\mathrm{ECT}(-1)$} & -0.3838 & 0.0193 & 0.0045 & -0.0311 & -0.1133 \\
\hline & $(0.0000)^{* * * *}$ & $(0.2450)$ & $(0.7925)$ & $(0.1129)$ & $(0.0276)^{* *}$ \\
\hline
\end{tabular}

Note: ***, ${ }^{* *}$ and $*$ denote significance at $1 \%, 5 \%$ and $10 \%$ levels, respectively.

Table-18. Financial liberalization long run result.

\begin{tabular}{c|c|c|c|c|c}
\hline \multicolumn{7}{c}{ Table-18. Financial liberalization long run result. } \\
\hline Variable & INT & CCH & EXC & ASP & IEC \\
\hline FLO* MPR & -0.4914 & 1290.12 & -44.716 & 14613 & -0.8924 \\
\hline FLO & $(0.0320)^{* *}$ & $(0.7938)$ & $(0.8192)$ & $(0.7507)$ & $(0.3100)$ \\
\hline & 6.3909 & -33161 & -640.08 & -259240 & 214.88 \\
\hline MPR & $(0.0731)^{*}$ & $(0.6871)$ & $(0.8460)$ & $(0.7524)$ & $(0.2055)$ \\
\hline C & 0.4942 & 2340.32 & -122.04 & -772.13 & 0.1598 \\
\hline & $(0.0412)^{* *}$ & $(0.7133)$ & $(0.8040)$ & $(0.7260)$ & $(0.9477)$ \\
\hline Adj. R ${ }^{2}$ & 5.257 & -59804 & 584.988 & 31886 & 3.2179 \\
\hline Serial Correlation & $(0.1171)$ & $(0.5755)$ & $(0.7701)$ & $(0.3012)$ & $(0.9037)$ \\
\hline Heteroscedasticity & 0.8887 & 0.9738 & 0.9817 & 0.9697 & 0.8205 \\
\hline N & 0.4312 & 0.8351 & 0.3481 & 0.5923 & 0.1258 \\
\hline
\end{tabular}

Note: ***, *** and * denote significance at $1 \%, 5 \%$ and $10 \%$ levels, respectively 


\section{Conclusion and Policy Recommendation}

This paper explored the impact of financial development on monetary transmission mechanism in Nigeria. Based on the findings from the analyses, the paper showed that financial development indicators and their interactions with the policy rate influenced each channel of monetary policy to different degrees. Banking sector indicators (size and activity measures) had more influence on the channels of monetary policy compared to capital market indicators, while financial market liberalization had the least influence on the channels of monetary policy. However, the significance of the individual financial development indicators was found to be very weak on exchange rate channel, while the influence of the financial market indicators was strongest on the interest rate channel, thereby supporting previous studies that interest rate channel is the most dominant channel of monetary policy for Nigeria. Consequently, financial development can be used as a tool to strengthen monetary transmission mechanism in Nigeria. In light of the above, efforts must be directed by all stakeholders to ensure that financial system reforms are geared towards the strengthening and implementation of monetary policy and the channels through which monetary policies impact an economy.

\section{References}

Adesoye, A. (2014). Dynamics of monetary policy and output nexus in Nigeria. Dynamics, 4(14), $22-33$.

Akpan, E. S. (2011). Nigerian financial institutions in David O. Mbat (Ed). Topical Issues in Finance (pp. 24-71). Calabar: University of Calabar Press.

Alfaro, R., Franken, H., García, C., \& Jara, A. (2003). Bank lending channel and themonetary transmission mechanism: The case of Chile. Central Bank of Chile Working Papers, No. 223, $1-25$.

Alpanda, S., \& Aysun, U. (2012). Global banking and the balance sheet channel of monetary transmission. International Journal of Central Banking, 8(3), 141-175.

Apanisile, O. T., \& Osinubi, T. T. (2019). Financial development and the effectiveness of monetary policy channels in Nigeria: A DSGE approach. Journal of African Business, 1 - 22.Available at: 10.1080/15228916.2019.1625021.

Aysun, U., Brady, R., \& Honig, A. (2012). Financial frictions and the credit channel of monetary transmission. Paper presented at the WEAI and Midwest Macro Conferences.

Babajide, A. A. (2011). The relationship between the informal and formal financial sector in Nigeria: A case study of selected groups in Lagos metropous. International Journal of Research in Computer Application and Management, 1(10), 24-32.

Bean, C., Larsen, J. D., \& Nikolov, K. (2002). Financial frictions and the monetary transmission mechanism: Theory, evidence and policy implications. ECB Working Paper No 113. Paper presented at the Monetary Transmission Network Conference atECB, Frankfurt.

Billi, R. M., \& Vredin, A. (2014). Monetary policy and financial stability - a simple story. Riksbank Economic Revierw, No. 2, 7-22.

Brunner, K., \& Meltzer, A. H. (1963). The place of financial intermediaries in the transmission of monetary policy. The American Economic Review, 53(2), 372-382.

Central Bank of Nigeria. (2017). CBN statistical bulletin and annual report. Central Bank of Nigeria. Retrieved from: http://www.cbn.gov.ng.

Chinn, M. Z., \& Ito, H. (2017). Notes on the Chinn-Ito financial openness index -2015 update. Retrieved from http://web.pdx.edu/ ito/Chinn-Ito_website.htm.

Christensen, I., Fung, B., \& Meh, C. (2006). Modelling financial channels for monetary policy analysis. Bank of Canada Review, Autumn, 2006(Autumn), 33-40.

Claus, I., \& Grimes, A. (2003). Asymmetric information, financial intermediation and the monetary transmission mechanism: A critical review. New Zealand Treasury Working Paper, 3(19), 1-24.

Claus., I., \& Smith, C. (1999). Financial intermediation and the monetary transmission mechanism. Reserve Bank of New Zealand: Bulletin, $62(4), 4-16$.

Devereux, M. B., \& Sutherland, A. (2007). Financial globalization and monetary policy. IMF Working Paper/o7/279, $1-32$.

Doguwa, S. I., Olowofeso, O. E., Uyaebo, S. O., Adamu, I., \& Bada, A. S. (2014). Structural breaks, cointegration and demand for money in Nigeria. CBN Journal of Applied Statistics, 5(1), 15-33.

Effiong, E., Esu, G., \& Chuku, C. (2017). Financial development and monetary policy effectiveness in Africa. MPRA Paper No. 79732. Retrieved from: https://mpra.ub.uni-muenchen.de/79732/.

Goldberg, L. S. (2013). Banking globalization, transmission, and monetary policy autonomy. National Bureau of Economic Research. Penning- och valutapolitik, Jubileum Snummer, 3.

Hwa, T. B. (2015). The transmission of financial stress and its interactions with monetary policy responses in the ASEAN-5 economies. Bank Negara Malaysia Working Papers, 6, 1 - 33.

Ikhide, S. (1996). Financial sector reforms and monetary policy in Nigeria. Institute of Development Studies, Working Paper No. 68.

Jegede, A. C. (2014). Effects of monetary policy on the commercial banks lending in Nigeria. Review of Public Administration and Management, $400(3614), 1-13$

Johnston, R., \& Sundararajan, V. (1999). Sequencing financial sector reforms: Country experiences and issues. Washington, DC: IMF.

Kryvtsov, O., Molico, M., \& Tomlin, B. (2015). On the nexus of monetary policy and financial stability: Recent developments and research. Bank of Canada Discussion Paper. No 2015-7. Retrieved from: http://hdl.handle.net/10419/129686.

Lerskullawat, A. (2014). Financial development and monetary policy transmission: The case of Thailand. An Unpublished PhD. Thesis Submitted to The University of Birmingham, England.

Mohan, R. (2006). Financial sector reforms and monetary policy: The Indian experience reserve Bank of India Bulletin. Paper presented at the Stanford Center for International Development and Stanford Institute for Economic Policy Research.

Montiel, P., Adam, C., Mbowe, W., \& O'Connell, S. (2012). Financial architecture and the monetary transmission mechanism in Tanzania. CSAE Working Paper Series No 03. 1 - 43.

Nissanke, M. (2010). The global financial crisis and the developing world: Transmission channels and fall-outs for industrial development. Research and Statistics Branch Working Paper No. 06/2009, 1 - 64.

Otalu, J. A., Aladesanmi, K. A., \& Olufayo, M. B. (2014). Monetary policy and commercial banks performance in Nigeria: An assessment of credit creation role. The International Journal of Business and Management, 2(7), 45 - 51.

Ozşuca, E. A. (2012). Banks and monetary policy transmission mechanism: An empirical analysis for Turkey. An Unpublished PhD. Thesis Submitted to The Graduate School of Social Sciences, Middle East Technical University, Turkey.

Perron, P. (2006). Dealing with structural breaks. Paper Prepared for the Palgrave Handbook of Econometrics. Economic Theory, 1, $278-352$.

Pesaran, M. H., Shin, Y., \& Smith, R. J. (2001). Bounds testing approaches to the analysis of level relationships. Journal of Applied Econometrics, 16(3), 289-326.Available at: https://doi.org/10.1002/jae.616.

Singh, S., Razi, A., Endut, N., \& Ramlee, H. (2007). Impact of financial market developments on the monetary transmission mechanism. BIS Papers No. 39, $49-99$.

Sirivedhin, T. (1998). Financial reform and the monetary transmission mechanism: The case of Thailand in in the transmission of monetary policy in emerging market economies. BIS Working Paper No. 3. $195-222$.

Spiegel, M. M. (2008). Financial globalization and monetary policy discipline: A survey with new evidence from financial remoteness. Center for Pacific Basin Studies, Economic Research Department, Federal Reserve Bank of San Francisco, Working Paper, $10,1-35$.

Tayssir, O., \& Feryel, O. (2017). Does central banking promote financial development? Borsa Istanbul Review, $18(1), 52-75$.

Visco, I. (2007). Financial deepening and the monetary policy transmission mechanism. Paper presented at the Exchange, IV Joint High-Level Eurosystem - Bank of Russia Seminar, Moscow, 10-12 October. 
Zivot, E., \& Andrew, D. W. K. (1992). Further evidence on the great crash, the oil- price shock and the unit root hypothesis. Journal of Business andEconomic Statistics, 10(3), 251 -270.

\section{Appendix}

Table-11. Activity measure of capital market development short run result.

\begin{tabular}{|c|c|c|c|c|c|}
\hline Variable & INT & $\mathrm{CCH}$ & EXC & ASP & IEC \\
\hline \multirow[t]{2}{*}{ Lag of Dependent Variable $(-1)$} & 0.3115 & & & 0.4329 & 0.1368 \\
\hline & $(0.0002)^{* * * *}$ & & & $(0.0000)^{* * *}$ & $(0.1496)$ \\
\hline \multirow[t]{2}{*}{ Lag of Dependent Variable (-2) } & 0.1494 & & & -0.1472 & \\
\hline & $(0.0854)^{*}$ & & & $(0.0828)^{*}$ & \\
\hline \multirow[t]{2}{*}{$\mathrm{D}(\mathrm{CMDA} * \mathrm{MPR})$} & -0.0094 & -13.3232 & -0.0757 & -154.09 & -0.0314 \\
\hline & $(0.5457)$ & $(0.4576)$ & $(0.3894)$ & $(0.0005)^{* * *}$ & $(0.6188)$ \\
\hline \multirow[t]{2}{*}{$\mathrm{D}(\mathrm{CMDA}(-1) * \operatorname{MPR}(-1))$} & & 16.2277 & & 90.7691 & \\
\hline & & $(0.1121)$ & & $(0.0444)^{* * *}$ & \\
\hline \multirow[t]{2}{*}{$\mathrm{D}(\mathrm{CMDA})$} & 0.0421 & 367.2100 & 0.4772 & 3361.12 & 0.3539 \\
\hline & $(0.8441)$ & $(0.1236)$ & $(0.6749)$ & $(0.0000) * * *$ & $(0.6698)$ \\
\hline \multirow[t]{2}{*}{$\mathrm{D}(\mathrm{CMDA}(-1))$} & & & & -1674 & \\
\hline & & & & $(0.025)^{* *}$ & \\
\hline \multirow[t]{2}{*}{$\mathrm{D}(\mathrm{MPR})$} & 0.0199 & -39.5019 & 0.2806 & -89.3473 & 0.2209 \\
\hline & $(0.8245)$ & (0.5313) & (0.3988) & $(0.2227)$ & (0.3550) \\
\hline \multirow[t]{2}{*}{$\mathrm{D}(\mathrm{MPR}(-3))$} & -0.1626 & & & & \\
\hline & $(0.0733)^{*}$ & & & & \\
\hline \multirow[t]{2}{*}{ DU_2005Q1 } & 0.5494 & & & & \\
\hline & $(0.4315)$ & & & & \\
\hline \multirow[t]{2}{*}{ DU_2011Q4 } & 0.0626 & & & & \\
\hline & (0.9263) & & & & \\
\hline \multirow[t]{2}{*}{ DU_2013Q2 } & & 4961.1611 & & & \\
\hline & & $(0.0001)^{* * *}$ & & & \\
\hline \multirow[t]{2}{*}{ DU_2009Q3 } & & & & 183.09 & \\
\hline & & & & $(0.7848)$ & \\
\hline \multirow[t]{2}{*}{ DU_1992Q2 } & & & & & 3.5097 \\
\hline & & & & & $(0.2456)$ \\
\hline \multirow[t]{2}{*}{ DU_1997Q1 } & & & & & -7.6060 \\
\hline & & & & & $(0.0240)^{* *}$ \\
\hline \multirow[t]{2}{*}{$\operatorname{ECT}(-1)$} & -0.3419 & -0.0917 & 0.0237 & -0.0368 & -0.2483 \\
\hline & $(0.0000) * * *$ & $(0.0049)^{* * *}$ & $(0.0852)^{*}$ & $(0.1968)$ & $(0.0003)^{* * * *}$ \\
\hline
\end{tabular}

Note: ***,** and $*$ denote significance at $1 \%, 5 \%$ and $10 \%$ levels, respectively.

Table-12. Activity measure of capital market development long run result

\begin{tabular}{|c|c|c|c|c|c|}
\hline Variable & INT & $\mathrm{CCH}$ & $\overline{\text { EXC }}$ & ASP & IEC \\
\hline \multirow[t]{2}{*}{ CMDA* MPR } & -0.0276 & -366.794 & 3.1933 & 1544 & -0.1265 \\
\hline & $(0.5431)$ & $(0.0861)^{*}$ & $(0.3984)$ & $(0.3120)$ & $(0.6216)$ \\
\hline \multirow[t]{2}{*}{ CMDA } & 0.1230 & 4006 & -20.119 & -15228 & 1.4254 \\
\hline & $(0.8437)$ & $(0.1314)$ & $(0.6746)$ & $(0.4020)$ & $(0.6725)$ \\
\hline \multirow[t]{2}{*}{ MPR } & 1.1806 & -430.9697 & -11.831 & -2429 & 0.8898 \\
\hline & $(0.0000)^{* * * *}$ & $(0.5284)$ & $(0.3851)$ & $(0.3330)$ & $(0.3636)$ \\
\hline \multirow[t]{2}{*}{ DU_2005Q1 } & 1.6069 & & & & \\
\hline & $(0.4523)$ & & & & \\
\hline \multirow[t]{2}{*}{ DU_2011Q4 } & 0.1831 & & & & \\
\hline & $(0.9259)$ & & & & \\
\hline \multirow[t]{2}{*}{ DU_2013Q2 } & & 54127 & & & \\
\hline & & $(0.0000)^{* * *}$ & & & \\
\hline \multirow[t]{2}{*}{ DU_2009Q3 } & & & & 4977 & \\
\hline & & & & $(0.7580)$ & \\
\hline \multirow{2}{*}{$\mathrm{DU}_{-1992 \mathrm{Q}^{2}}$} & & & & & 14.1357 \\
\hline & & & & & $(0.1719)$ \\
\hline \multirow{2}{*}{ DU_1997Q1 } & & & & & -30.6335 \\
\hline & & & & & $(0.0006)^{* * * *}$ \\
\hline \multirow[t]{2}{*}{$\mathrm{C}$} & -3.7966 & 9686 & 134.31 & 50992 & 15.7221 \\
\hline & $(0.3040)$ & $(0.3737)$ & $(0.5197)$ & $(0.2400)$ & $(0.3519)$ \\
\hline Adj. $\mathrm{R}^{2}$ & 0.8797 & 0.9763 & 0.9818 & 0.9787 & 0.8132 \\
\hline Serial Correlation & 0.4469 & 0.4149 & 0.5242 & 0.3583 & 0.2805 \\
\hline Heteroscedasticity & 0.0984 & 0.7530 & 0.9145 & 0.0664 & 0.7438 \\
\hline
\end{tabular}




\begin{tabular}{|c|c|c|c|c|c|}
\hline Variable & INT & $\mathrm{CCH}$ & EXC & ASP & IEC \\
\hline \multirow[t]{2}{*}{$\begin{array}{l}\text { Lag of Dependent } \\
\text { Variable }(-1)\end{array}$} & 0.3217 & & & 0.4780 & 0.1406 \\
\hline & $(0.0001)^{* * * *}$ & & & $(0.0000)^{* * * *}$ & $(0.1464)$ \\
\hline \multirow[t]{2}{*}{$\begin{array}{ll}\text { Lag of } & \text { Dependent } \\
\text { Variable }(-2) & \\
\end{array}$} & 0.1906 & & & & \\
\hline & $(0.0245)^{* * *}$ & & & & \\
\hline \multirow[t]{2}{*}{$\mathrm{D}\left(\mathrm{FEF}^{*} \mathrm{MPR}\right)$} & -0.7723 & -900.13 & -4.9637 & 13381 & -0.9976 \\
\hline & $(0.3383)$ & $(0.3251)$ & $(0.2803)$ & $(0.0021)^{* * *}$ & $(0.7653)$ \\
\hline \multirow[t]{2}{*}{$\mathrm{D}(\mathrm{FEF}(-1) * \operatorname{MPR}(-1))$} & 0.1837 & & & 7422 & \\
\hline & $(0.7224)$ & & & $(0.1057)$ & \\
\hline \multirow[t]{2}{*}{$\mathrm{D}(\mathrm{FEF}(-2) * \operatorname{MPR}(-2))$} & 0.6573 & & & -13484 & \\
\hline & $(0.1026)$ & & & $(0.0014)^{* * * *}$ & \\
\hline \multirow[t]{2}{*}{$\mathrm{D}(\mathrm{FEF})$} & 7.9135 & 12073 & 42.6446 & -159718 & 22.5765 \\
\hline & $(0.4611)$ & $(0.3606)$ & $(0.5072)$ & $(0.0027)^{* * * *}$ & $(0.6330)$ \\
\hline \multirow[t]{2}{*}{$\mathrm{D}(\mathrm{FEF}(-2))$} & & & & 150564 & \\
\hline & & & & $(0.0028)^{* * * *}$ & \\
\hline \multirow[t]{2}{*}{$\mathrm{D}(\mathrm{MPR})$} & 0.0278 & 5.7090 & 0.5404 & -25.5036 & 0.268988 \\
\hline & $(0.7814)$ & $(0.9462)$ & $(0.2239)$ & $(0.7301)$ & $(0.4015)$ \\
\hline \multirow[t]{2}{*}{$\mathrm{D}(\mathrm{MPR}(-3))$} & -0.1877 & & & & \\
\hline & $(0.0359)^{* *}$ & & & & \\
\hline \multirow[t]{2}{*}{ DU_2011Q4 } & 0.7036 & & & & \\
\hline & $(0.0903)^{*}$ & & & & \\
\hline \multirow{2}{*}{ DU_2013Q2 } & & 3654 & & & \\
\hline & & $(0.0009)^{* * * *}$ & & & \\
\hline \multirow[t]{2}{*}{ DU_2003Q4 } & & & & 4049 & \\
\hline & & & & $(0.0001)^{* * * *}$ & \\
\hline \multirow[t]{2}{*}{ DU_2008Q2 } & & & & -2479 & \\
\hline & & & & $(0.0043)^{* * * *}$ & \\
\hline \multirow[t]{2}{*}{ DU_2012Q4 } & & & & 1097 & \\
\hline & & & & $(0.1973)$ & \\
\hline \multirow[t]{2}{*}{ DU_1992Q2 } & & & & & 3.1139 \\
\hline & & & & & $(0.2929)$ \\
\hline \multirow[t]{2}{*}{ DU_1997Q2 } & & & & & -7.4312 \\
\hline & & & & & $(0.0297)^{* * *}$ \\
\hline \multirow[t]{2}{*}{$\operatorname{ECT}(-1)$} & -0.4197 & -0.0636 & 0.0241 & -0.1173 & -0.2352 \\
\hline & $(0.0000)^{* * * *}$ & $(0.0328)^{* * *}$ & $(0.0798)^{*}$ & $(0.0002)^{* * * *}$ & $(0.0004)^{* * * *}$ \\
\hline
\end{tabular}
Note: ******* and $*$ denote significance at $1 \%, 5 \%$ and $10 \%$ levels, respectively.

Table-14. Financial market efficiency long run result.

\begin{tabular}{|c|c|c|c|c|c|}
\hline Variable & INT & $\mathrm{CCH}$ & EXC & ASP & IEC \\
\hline \multirow[t]{2}{*}{$\mathrm{FEF}^{*} \mathrm{MPR}$} & -3.2571 & -14162 & 205.887 & 197877 & -4.2422 \\
\hline & $(0.0749)^{*}$ & $(0.3334)$ & $(0.3115)$ & (0.0128)** & $(0.7672)$ \\
\hline \multirow[t]{2}{*}{$\mathrm{FEF}$} & 18.8567 & 189962 & -1769 & -2294313 & 95.9991 \\
\hline & $(0.4607)$ & $(0.3627)$ & $(0.5194)$ & $(0.0177)^{* * *}$ & $(0.6374)$ \\
\hline \multirow[t]{2}{*}{ MPR } & 1.1497 & 89.8304 & -22.41 & -217.49 & 1.1438 \\
\hline & $(0.0000)^{* * * *}$ & $(0.9462)$ & $(0.2368)$ & $(0.7253)$ & $(0.4123)$ \\
\hline \multirow[t]{2}{*}{ DU_2011Q4 } & 1.6765 & & & & \\
\hline & $(0.0788)^{*}$ & & & & \\
\hline \multirow[t]{2}{*}{ DU_2013Q2 } & & 57502 & & & \\
\hline & & $(0.0002)^{* * * *}$ & & & \\
\hline \multirow[t]{2}{*}{ DU_2003Q4 } & & & & 34526 & \\
\hline & & & & $(0.0000)^{* * * *}$ & \\
\hline \multirow{2}{*}{ DU_2008Q2 } & & & & -21136 & \\
\hline & & & & $(0.0185)^{* * *}$ & \\
\hline \multirow[t]{2}{*}{ DU_2012Q4 } & & & & 9355 & \\
\hline & & & & $(0.1850)$ & \\
\hline \multirow[t]{2}{*}{ DU_1992Q2 } & & & & & 13.241 \\
\hline & & & & & $(0.2258)$ \\
\hline \multirow[t]{2}{*}{ DU_1997Q2 } & & & & & -31.5989 \\
\hline & & & & & $(0.0015)^{* * * *}$ \\
\hline \multirow[t]{2}{*}{$\mathrm{C}$} & -1.7462 & 3104 & 250.45 & 9001 & 10.6306 \\
\hline & $(0.5553)^{*}$ & $(0.8831)$ & $(0.3557)$ & $(0.3800)$ & $(0.6444)$ \\
\hline Adj. $\mathrm{R}^{2}$ & 0.8868 & 0.9735 & 0.9818 & 0.9771 & 0.8125 \\
\hline Serial Correlation & 0.4754 & 0.6732 & 0.5129 & 0.3232 & 0.4228 \\
\hline Heteroscedasticity & 0.1321 & 0.9162 & 0.9189 & 0.4684 & 0.7551 \\
\hline
\end{tabular}

